\title{
E 006300
}

${ }^{1}$ Курский государственный медицинский университет

${ }^{2}$ Медицинский иентр «Тандем-Плюс», Яроставль

\section{Антиоксидантное сопровождение фармакотерапии хронического простатита: патогенетическая целесообразность и эффективность}

\author{
О.И. Братчиков, д.м.н., проф. ${ }^{1}$, И.А. Тюзиков, к.м.н. ${ }^{2}$, П.А. Дубонос ${ }^{1}$ \\ Адрес для переписки: Игорь Адамович Тюзиков, phoenix-67@list.ru \\ Для цитирования: Братчиков О.И., Тюзиков И.А., Дубонос П.А. Антиоксидантное сопровождение фармакотерапии хронического \\ простатита: патогенетическая целесообразность и эффективность // Эффективная фармакотерапия. 2019. Т. 15. № 29. С. 56-66. \\ DOI 10.33978/2307-3586-2019-15-29-56-66
}

В настоящее время одной из наиболее популярных и доказанных теорий старения и патогенеза заболеваний человека является свободнорадикальная теория (теория окислительного стресса), в рамках которой окислительный стресс рассматривается в качестве ключевого универсального механизма старения и патогенеза подавляющего большинства современных заболеваний человека. В обзорной статье на основе актуальных клинико-экспериментальных исследований обсуждаются общие вопросы патофизиологии окислительного стресса и его роль в патогенезе хронического простатита. Фармакологическим воплощзением теории окислительного стресса стали синтез и внедрение в клиническую практику большого количества антиоксидантов, число которых постоянно растет. Антиоксиданты существенно отличаются друг от друга как по химической структуре, так и по функииональной нагрузке и точке приложения эффектов. В этой связи в каждой отрасли медицины к настоящему времени сформировался свой круг антиоксидантов, наиболее изученных и эфбективных с точки зрения доказательной медицины и фармакологии. В статье представлен обзор современных антиоксидантов, перспективных с точки зрения применения в комплексной фармакотерапии хронического простатита, а также проведен анализ доступных исследований их эбфективности. На основе данных литературы, отражающих существенную роль окислительного стресса в патогенезе хронического простатита, сделан вывод о иелесообразности и эффективности включения антиоксидантов в комплексное лечение хронического простатита с иелью повышения эфбективности терапии данного заболевания.

Ключевые слова: хронический простатит, окислительный стресс, активные формы кислорода, перекисное окисление типидов, антиоксидантная система защиты, антиоксиданты 


\section{Введение}

Хронический простатит (ХП) одно из наиболее распространенных урологических заболеваний у мужчин. С точки зрения этиопатогенеза ХП представляет собой гетерогенную группу воспалительных заболеваний предстательной железы [1-5]. Согласно современным представлениям, термин «простатит», который ранее использовался для обозначения любых воспалительных заболеваний предстательной железы, сегодня может применяться только в отношении инфекционного острого или хронического простатита. Для обозначения «неинфекционных» форм заболевания следует использовать термины «синдром хронической тазовой боли» и «простатический болевой синдром» [6]. Выделение инфекционных и неинфекционных форм простатита в клинической практике основано преимущественно на результатах микробиологических исследований секрета предстательной железы, которые не всегда адекватно, полноценно и объективно отражают истинный микробный пейзаж, поэтому многие эксперты находят такое деление весьма условным [7]. ХП характеризуется высокой медико-социальной значимостью, поскольку чаще всего отмечается у мужчин трудоспособного и репродуктивного возраста - от 20 до 45 лет, но может встречаться в любом возрасте. Более того, вероятность заболевания простатитом в 50-59 лет в 3 раза выше, чем в 20-39 лет [8]. С патогенетической точки зрения совершенно справедливо мнение ряда экспертов о том, что ХП представляет собой «мультифакторный взаимосвязанный каскад» патологических превращений, которые инициируются тем или иным агентом (событием или процессом) и приводят к возникновению симптомов и локальной боли [9]. В этой связи большинство исследователей и клиницистов сходятся в том, что не существует единого, убедительного с позиций доказательной медицины этиологического фактора и универсального патогенетического механизма ХП. Это позволяет на сегодняшний день считать ХП многофакторным заболеванием (или даже синдромом) и позиционировать его как междисциплинарную проблему, которая должна обсуждаться с позиций тесного патогенетического взаимодействия разнонаправленных системных и органных нарушений с точкой приложения эффектов в предстательной железе [10-12]. В качестве одного из таких универсальных патофизиологических механизмов многофакторного патогенеза ХП рассматривается окислительный стресс [13-17].

\section{Роль окислительного стресса в патогенезе хронического простатита}

Окислительный стресс представляет собой неконтролируемый каскадно протекающий процесс избыточного образования внутри клетки и/или избыточного поступления извне в клетку свободных радикалов. Этот процесс достаточно быстро способен привести к декомпенсации естественной системы антиоксидантной защиты клетки. В результате происходит нарушение анатомической целостности всех структур клетки, прогрессирование функциональных клеточных дефицитов, клетка теряет способность к репарации и апоптозу [18].

Источником активных форм кислорода в секрете предстательной железы при ХП могут быть лейкоциты (в норме они присутствуют в секрете железы, но их уровень существенно повышается при воспалительных заболеваниях), непосредственно патогенные микроорганизмы, синтезирующие активные формы кислорода в процессе жизнедеятельности, и их токсины, а также антиспермальные антитела. Последние образуются в ответ на микробные факторы агрессии или при иммунном воспалении в ткани предстательной железы, которое может персистировать даже после эрадикации возбудителя [19-22].
Лейкоциты в физиологических условиях производят в 1000 раз больше активных форм кислорода, чем сперматозоиды. Существует мнение, что такой высокий уровень продукции свободных радикалов лейкоцитами необходим для защиты клеток от инфекций и воспаления [23]. Однако лейкоцитоспермия может быть также результатом воздействия факторов неинфекционной природы, например длительного сексуального воздержания или «компрессионной» патологии органов мошонки (варикоцеле, гидроцеле, пахово-мошоночные грыжи). Кроме того, лейкоцитоспермия может быть асептической по природе (в частности, при ожирении), и тогда при микробиологических исследованиях эякулята инфекционный агент чаще всего не культивируется [24-26].

Одни авторы считают, что при ХП существует прямая зависимость между количеством лейкоцитов и уровнем образования активных форм кислорода [27]. Другие полагают, что нет существенных отличий между концентрациями лейкоцитов в сперме здоровых мужчин и мужчин с ХП [28].

Патогенные микроорганизмы в секрете предстательной железы при инфекционном ХП могут быть важнейшими продуцентами активных форм кислорода. При исследовании параметров перекисного статуса спермоплазмы выявлено, что уровень промежуточных интермедиатов перекисного окисления липидов (ПОЛ) в спермоплазме у больных ХП больше чем в 2 раза превышал таковой у здоровых мужчин. Кроме того, в группе больных ХП регистрировался максимальный дефицит факторов антиоксидантной системы защиты (AOC3), а у мужчин без воспаления в органах мочеполовой системы нарушения перекисного статуса были минимальными [29, 30].

Под влиянием активных форм кислорода в клетке развиваются ключевые патофизиологические процессы, приводящие сначала к ее дисфункции, а затем к гибели. 
Прежде всего усиливаются процессы ПОЛ, в том числе входящих в состав клеточных мембран [31]. ПОЛ - нормальный метаболический процесс, широко представленный во всех клетках и органах организма, одна из разновидностей процессов свободнорадикального окисления. В качестве субстрата ПОЛ преимущественно использует ненасыщенные жирные кислоты фосфолипидов биологических мембран с образованием цикличных эндоперекисей и гидроперекисей. В качестве промежуточных продуктов ПОЛ в клетках рассматриваются малоновый диальдегид и диеновые конъюгаты, а конечными продуктами ПОЛ являются шиффовы основания [32]. Благодаря регуляции со стороны компонентов АОСЗ в норме реакции ПОЛ (как и их метаболических продуктов) в клетке поддерживаются на достаточно низком уровне. Однако при этом процессы ПОЛ активно участвуют во многих физиологических и биохимических процессах организма: модификации биологических мембран, метаболизме оксида азота (NO), регуляции окислительного фосфорилирования, биосинтезе простагландинов и стероидных гормонов, контроле клеточного деления, антимикробной системе фагоцитов. ПОЛ усиливается при снижении антиоксидантной активности клетки, повышении содержания полиненасыщенных жирных кислот, избытке катехоламинов, гипоксии и ишемии и т.д. $[31,32]$.

Усиление антиоксидантной активности клетки - не всегда благоприятный признак, но может свидетельствовать о начальном ответе на развивающийся окислительный стресс, сопровождающийся мобилизацией AOC3 и первоначальным ростом уровня отдельных антиоксидантов. Однако при большой выраженности или перманентности стрессорных окислительных влияний АОСЗ истощается. На фоне продолжающегося каскадного избыточного образования свободных радикалов и дефицита эндогенных антиоксидан- тов это приводит к чрезмерному накоплению в клетке продуктов ПОЛ, что нарушает ее метаболизм и энергетический обмен [33].

По данным одних авторов, при ХП происходит активация реакций ПОЛ и как следствие повышается активность АОС3 [34, 35]. Другие, напротив, указывают на ослабление процессов ПОЛ и активности АОСЗ при ХП. Столь противоречивые мнения, очевидно, объясняются разными подходами к оценке последовательности динамики клеточных оксидативных нарушений $[36,37]$. Развитие и прогрессирование окислительного стресса в клетке предъявляют высокие функциональные требования ко всем компонентам ее природной AOC3, и прежде всего к специализированным ферментным системам: супероксиддисмутазе, каталазе и глутатионпероксидазе.

Одни авторы, исследуя гомогенаты ткани предстательной железы на экспериментальных моделях аутоиммунного ХП, наблюдали существенное снижение активности каталазы и относительно стабильную концентрацию супероксиддисмутазы и глутатионпероксидазы [38]. По другим данным, активность супероксиддисмутазы в спермоплазме больных латентным ХП была статистически значимо ниже, чем у мужчин без воспалительных заболеваний репродуктивной системы. А у пациентов с ХП, сопровождающимся нарушением фертильности, активность каталазы была статистически достоверно ниже, чем в группе здоровых фертильных мужчин. Однако активность прооксидантных ферментов и процессов ПОЛ в спермоплазме при активном воспалении, напротив, выросла $[39,40]$.

По данным одного из недавних метаанализов, ХП достоверно ассоциируется со снижением концентрации некоторых кофакторов ключевых ферментов АОСЗ в секрете предстательной железы, в частности цинка - доказанного и эффективного антиоксиданта [41].
Клинико-экспериментальные исследования продемонстрировали, что плазменная активность супероксиддисмутазы, каталазы и глутатионпероксидазы на фоне усиления реакций ПОЛ повышается на ранних стадиях ХП. Однако в дальнейшем, особенно при запоздалом лечении, на фоне прогрессирующего увеличения концентрации в плазме крови продуктов ПОЛ (в частности, малонового диальдегида) уровень всех вышеописанных ключевых ферментов AOC3 имеет тенденцию к снижению, что отражает высокий риск развития ее декомпенсации [42-44].

Таким образом, при развитии и персистенции в ткани предстательной железы хронического воспалительного процесса на клеточном уровне усиливаются проявления окислительного стресса, которые усугубляют патофизиологические механизмы, исходно приведшие к хроническому воспалению в железе. В связи с повышенной функциональной нагрузкой в условиях свободнорадикальной агрессии на все компоненты АОСЗ клетки существенно возрастает риск ее декомпенсации, что может замыкать «порочный патогенетический круг» ХП и существенно снижать эффективность даже адекватной индивидуальной фармакотерапии у больных ХП. Вот почему с учетом важнейшей роли окислительного стресса в патогенезе любых форм ХП патогенетически обоснованным новым фармакотерапевтическим методом становится широкое применение антиоксидантов в комплексном лечении как бактериальных, так и абактериальных форм ХП [45].

\section{Антиоксиданты, имеющие преимущества при хроническом простатите}

\section{Глутатион}

Этот естественный антиоксидант представляет собой содержащий серу трипептид и состоит из трех аминокислот: цистеина, глицина и глутамина. Аминокислоты содержат сульфгидрильную группу 
(SH), которая притягивает токсины подобно губке.

Глутатион естественным образом вырабатывается в печени человека. Его синтезу способствуют альфа-липоевая кислота, витамины C, E, B $, \mathrm{B}_{6}, \mathrm{~B}_{12}$, фолаты, селен, донаторы серы, магний, цинк, ванадий.

Глутатион присутствует в организме в восстановленной (GSH) и окисленной (GSSG) формах. Восстановленный глутатион - донатор электронов для глутатионпероксидазы, синтезируется de novo или в ходе рецикла глутатионпероксидазы, использующей никотинамиддинуклеотидфосфат как донатор электронов. Является универсальным «физиологическим» акцептором свободных радикалов [46]. Благодаря способности глутатиона уменьшать ПОЛ мембран клеток его считают перспективным антиоксидантом при воспалительных заболеваниях предстательной железы.

Назначение глутатиона в дозе 600 мг/сут бесплодным мужчинам с односторонним варикоцеле или ХП приводило к существенному улучшению параметров эякулята, таких как концентрация, подвижность и морфология, на фоне купирования симптомов заболевания [47].

\section{Карнитин}

Наиболее известная молекула с антиоксидантным действием карнитин существует в формах: L-карнитин и ацетил-L-карнитин. L-карнитин, как известно, главный эндогенный кофактор транспорта длинноцепочечных бета-жирных кислот в митохондриальный матрикс для их дальнейшей утилизации в процессе синтеза клеточной энергии (карнитиновый челночный механизм).

В высокой концентрации он присутствует в придатках яичек, что позволяет говорить о его критической роли в спермальном синтезе энергии и созревании сперматозоидов. Некоторые исследования продемонстрировали уменьшение концентрации L-карнитина в эякуляте больных эпидидимитом [48].
Результаты исследований показывают, что ввиду значительного уровня окислительного стресса при ХП (в том числе при его абактериальной форме) применение L-карнитина патогенетически обосновано. Лучшей тактикой в этом случае считается его применение на фоне курсов антибиотиков и нестероидных противовоспалительных препаратов или после них [49]. Рекомендуется принимать не менее 2 г/сут L-карнитина и 1 г/сут ацетил-L-карнитина на протяжении не менее трех месяцев [45].

\section{$\mathrm{N}$-ацетилцистеин}

Существенно увеличивает объем спермы и ее разжижает. Способен улучшать течение каррагинаниндуцированного экспериментального простатита, снижая выраженность воспаления посредством регуляции сигнальной системы Keap1/Nrf2/ARE [15, 50]. Чаще всего назначается в дозе 600 мг/сут на срок не менее трех месяцев. Входит в состав ряда коммерческих комбинированных препаратов [45].

\section{Коэнзим $Q_{10}$}

Единственный жирорастворимый антиоксидант, который синтезируется в клетках из аминокислоты тирозина при участии витаминов $\mathrm{B}_{2}, \mathrm{~B}_{3}, \mathrm{~B}_{6}, \mathrm{~B}_{12}, \mathrm{C}$, фолиевой и пантотеновой кислот и ряда микроэлементов, а также постоянно регенерируется из окисленной формы с помощью ферментных систем организма.

Коэнзим $\mathrm{Q}_{10}$ присутствует в трех формах: убихинон $\left(Q_{10}\right.$ окисленный), убихинол $\left(Q_{10 \mathrm{H} 2}\right.$ восстановленный) и семихинон (частично окисленный радикал). Восстановленная форма (убихинол) обладает более выраженными антиоксидантными свойствами и составляет около $90 \%$ от всего количества коэнзима $\mathrm{Q}_{10}$ в организме.

Важнейшая биологическая роль коэнзима $\mathrm{Q}_{10}$ определяется его участием в митохондриальной цепи электронного транспорта
В качестве кофермента. В настоящее время можно считать доказанным, что убихинон, кроме переноса электронов и протонов в митохондриях, выполняет еще одну значимую функцию, образуя окислительно-восстановительную систему «убихинол - убихинон».

Антиоксидантное действие коэнзима $\mathrm{Q}_{10}$ главным образом заключается в предотвращении образования и устранении свободных липидных радикалов, а при концентрациях убихинона, существующих в митохондриях, он способен выполнять роль ловушки супероксидного анион-радикала. Главное его достоинство как антиоксиданта - относительно небольшая токсичность $[51,52]$.

В яичках идет постоянный биосинтез коэнзима $\mathrm{Q}_{10}$, а его спермальная концентрация строго коррелирует с количеством, подвижностью и морфологией сперматозоидов.

Убихинол обычно назначается в дозе 150-200 мг/сут в течение не менее четырех месяцев [45].

\section{Карнозин (L-карнозин,}

бета-аланил-L-гистидин)

B организме L-карнозин образуется из бета-аланина и гистидина под действием карнозинсинтетазы, а в дальнейшем под влиянием N-метилтрансферазы и в присутствии S-аденозилметионина может превращаться в анзерин.

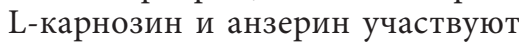
в формировании буферной системы организма, способны нейтрализовать активные формы кислорода и сахаров, являются буфером протонов и металлов переменной валентности [53]. Карнозин защищает белки от неэнзиматического гликозилирования (гликирования), поскольку представляет собой более удобную мишень для атаки альдегидами, а в высоких концентрациях - и от альдосахаров. L-карнозин связывается с карбонильными группами окисленных белков, а образующееся при этом карнозилированное производное белка быстрее подвергается протеолизу и выключается из клеточного метаболизма. 
Одновременно L-карнозин усиливает чувствительность тканей к инсулину. Содержание сахара и инсулина в крови понижается, что также защищает ткани от избыточного уровня глюкозы.

L-карнозин выводит из организма ферментные яды: ртуть, мышьяк, кадмий и свинец. Кроме того, он очищает организм от избытка железа, цинка и меди, прооксидантных металлов и вызывает окисление клеток [53].

Из-за повышенных физических нагрузок в мускулатуре скапливаются одновременно молочная кислота и активные формы кислорода. В результате перекрываются кальциевые каналы, мышцы перестают сокращаться. L-карнозин обезвреживает протоны и активные формы кислорода. Так снимается утомление мышц, они снова начинают сокращаться.

Основной сферой использования L-карнозина остается профессиональный спорт. Клиническое применение L-карнозина в качестве лекарственного средства пока ограничивается офтальмологией, однако широкий спектр действия позволяет рассматривать его в качестве одного из перспективных биоантиоксидантов и регуляторов клеточного метаболизма [53].

\section{Цинк}

Один из ключевых микроэлементов, обеспечивающих нормальное функционирование мужского урогенитального тракта. Он необходим для синтеза тестостерона, правильной работы рецепторов половых стероидных гормонов, созревания сперматозоидов и обеспечения природной бактерицидной функции предстательной железы (в эпителии простаты секретируется содержащий цинк простатический антибактериальный фактор полипептидной природы) [54]. В этой связи цинкзаместительная терапия ХП, при котором в разной степени угнетается секреторная функция простатического эпителия, считается патогенетически обоснованной фармакотерапевтической опцией, особенно при бактериальных формах заболевания.

Цинк обычно назначается перорально в дозе не менее 22 мг/сут на протяжении не менее трех-четырех месяцев в виде монотерапии или в комбинации с фолиевой кислотой (5 мг/сут) [45].

\section{Медь}

Необходимый микроэлемент для жизни растительных и животных организмов.

Во-первых, ионы меди по сравнению с ионами других металлов активнее реагируют и образуют более устойчивые комплексы с аминокислотами и белками. Вовторых, ионы меди служат исключительно эффективными катализаторами, особенно в сочетании с белками. В-третьих, медь легко переходит из одного валентного состояния в другое, что имеет особое значение при выполнении метаболических функций, например активации молекулы кислорода в реакциях окисления органических соединений.

Содержащие медь ферменты окисления оксигеназы присоединяют молекулу кислорода с образованием пероксидной цепочки и окислением меди из $\mathrm{Cu}^{+}$в $\mathrm{Cu}^{2+}$.

Важную физиологическую функцию выполняет фермент супероксиддисмутаза - один из ключевых специализированных ферментов AOC3. Он ускоряет реакцию разложения супероксид-иона $\mathrm{O}_{2}^{-}$, возникающего при свободнорадикальном окислении веществ в клетке. Этот радикал активно взаимодействует с разными компонентами клетки, разрушая их. Супероксиддисмутаза превращает супероксид-ион $\mathrm{O}_{2}^{-}$ в молекулярный кислород и пероксид водорода, причем атом меди фермента выступает и окислителем, и восстановителем.

В дыхательной цепи большую роль играет фермент цитохромоксидаза, которая кроме меди содержит еще и железо. Цитохромоксидаза катализирует перенос электронов от окисляемого вещества на молекулярный кислород. В ходе каталитического процесса степени окисления меди и железа обрати- мо изменяются, а восстанавливающийся кислород, присоединяя протоны, превращается в воду.

Разнообразные функции в организме выполняет медьсодержащий белок плазмы крови - церулоплазмин, также входящий в АОС3. В церулоплазмине присутствует 98\% меди, имеющейся в плазме крови, и он не только служит резервуаром для меди, но и выполняет транспортную функцию, регулируя баланс меди и обеспечивая выведение ее избытка из организма. Кроме того, церулоплазмин катализирует окисление $\mathrm{Fe}^{2+}$ в $\mathrm{Fe}^{3+}$, участвуя в кроветворении [55-57].

\section{Селен}

Под влиянием селена и содержащих селен ферментов происходит ингибирование активности протеинкиназы C, 5-липоксигеназы, циклооксигеназы и никотинамиддинуклеотидфосфат-оксидазы. Кроме того, выявлено синергичное действие селена с альфа-токоферолом.

К модуляторам активности антиоксидантных ферментов может быть отнесен селенит натрия. Его действие связывают с участием в активации антиоксидантной системы посредством энзима глутатионпероксидазы, активным центром которого является селен, соответственно, его недостаток может привести к снижению активности данного фермента.

Селензависимыми ферментами являются тиоредоксин редуктаза и 5-дейодиназа. Помимо этого селен входит в состав селенопротеинов $\mathrm{P}$ и $\mathrm{W}$, содержащихся в плазме [58].

\section{L-аргинин}

Представляет собой алифатическую основную альфа-аминокислоту, которая оптически активна и существует в виде $\mathrm{L}$ - и $\mathrm{D}$-изомеров. L-аргинин входит в состав пептидов и белков, особенно высоко содержание аргинина в основных белках гистонах и протаминах (до $85 \%$ ). $\mathrm{L}$-аргинин - субстрат для NOсинтаз в синтезе NO, локально- 
го тканевого эндотелиального и нейронального гормона с множественными эффектами от противовоспалительного до сосудистой модуляции (профилактика ишемии и гипоксии) и стимуляции ангиогенеза. Свободный радикал NO синтезируется в организме для обеспечения многих нормальных клеточных функций. Однако высокие уровни $\mathrm{NO}$, взаимодействуя с другими окислителями, образуют активные формы азота, которые повреждают клеточные мишени. Образуемый в реакции $\mathrm{NO} \mathrm{c} \mathrm{O}_{2}$ пероксинитрит - сильный окислитель, который вступает в реакции с различными биомолекулами (белками, липидами, ДНК). В условиях окислительного стресса присутствие L-аргинина обеспечивает наименьшие нарушения прооксидантно-антиоксидантного равновесия в системе тканей «L-аргинин - $\mathrm{NO}$ » [59-61].

\section{Ликопин}

Несколько клинико-экспериментальных исследований показали позитивные эффекты ликопина в отношении параметров эякулята за счет снижения ПОЛ мембран и повреждения ДНК сперматозоидов на фоне окислительного стресса. При его пероральном применении в дозе 2 г/сут в течение не менее трех месяцев достоверно улучшались концентрация и подвижность сперматозоидов. Кроме того, ликопин характеризуется онкопротективным эффектом в отношении рака предстательной железы [45].

\section{Ресвератрол}

Один из самых известных, хорошо изученных и эффективных современных антиоксидантов. Ресвератрол - природный фитоалексин, производное трансстильбена, относится к полифенолам. Он содержится в кожуре винограда и других фруктов, какао и орехах, а также в красном вине (в среднем 0,25,8 мг/л, в белом содержание ниже). Его также синтезируют некоторые растения в качестве защитной реакции против паразитов, таких как бактерии или грибы.

В экспериментах на животных выявлены противоопухолевое, противовоспалительное, кардиопротективное, гипогликеми ческое и другие положительные свойства ресвератрола.

В последние годы появились в основном экспериментальные работы о применении ресвератрола в комплексном лечении ХП для уменьшения выраженности окислительного стресса, но оптимальные дозировки и требуемые курсы терапии при данном заболевании для клинической практики пока не разработаны [62-65].

\section{Витамин A}

Вместе с бета-каротином (провитамином А) витамин А (ретинол) входит в естественную антиоксидантную систему клетки и оказывает определенное антиоксидантное действие, которое, однако, подтверждено преимущественно в экспериментальных исследованиях на животных. Согласно мембранной теории действия, витамин А способен проникать в гидрофобную зону биологических мембран и взаимодействовать с лецитино-холестериновыми монослоями на границе раздела фаз, вызывая перестройку мембран клетки, лизосом и митохондрий [66]. Витамин А обеспечивает целостность клеточных мембран, регулирует эпителиально-клеточную пролиферацию и вовлечен в регуляцию сперматогенеза, оказывая различное влияние на фетальные и неонатальные клетки Лейдига, клетки Сертоли и герминогенный эпителий яичек. Исследований по эффективности витамина А при инфекциях придаточных половых желез крайне мало [67].

\section{Провитамин А (бета-каротин)}

Как провитамин А (бета-каротин), так и каротиноиды, не способные к образованию витамина А, тоже выполняют антиоксидантные функции за счет изопреноидных участков в формуле. Они достаточно эффективно ловят синглетный кислород, в особенности при низком парциальном давлении кислорода. Кроме того, в этом случае они могут действовать и по другому механизму, выступая в качестве антиоксидантных соединений, обрывающих цепи ПОЛ. В то же время при высоком содержании кислорода бета-каротин может проявлять прооксидантную активность [66].

\section{Витамин C}

В организме витамин C способен образовывать окислительно-восстановительную пару «аскорбиновая кислота - дегидроаскорбиновая кислота», которая действует совместно с витамином Е. На границе раздела липиды/водная фаза аскорбиновая кислота обеспечивает защиту альфа-токоферола или восстанавливает его окисленную форму после действия свободных радикалов.

Витамин С может предотвращать или делать обратимым процесс окисления восстановленного глутатиона до его функционально неактивной формы. В отсутствие металлов переменной валентности (ионов железа и меди) он проявляет выраженный антиоксидантный эффект. В присутствии активной формы железа $\left(\mathrm{Fe}^{3+}\right)$ аскорбиновая кислота может восстанавливать его до двухвалентного железа $\left(\mathrm{Fe}^{2+}\right)$, способного высвобождать гидроксильный радикал по реакции Фентона, проявляя свойства прооксиданта [66].

В экспериментах доза витамина C, эквивалентная человеческой терапевтической дозе 10 мг/кг, уменьшала концентрацию малонового диальдегида (конечного продукта ПОЛ) в эякуляте с одновременным повышением количества и улучшением морфологии сперматозоидов. Большинство исследований 
витамина С посвящено его влиянию на фертильность, данных об антиоксидантных свойствах при ХП пока недостаточно для того, чтобы сделать определенные выводы [45].

\section{Витамин Е (альфа-токоферол)}

Наиболее изученный антирадикальный антиоксидант. Витамин Е - фактически общее название для группы токоферолов альфа-, бета- и гамма-, обладающих сходной биологической активностью. Однако наибольшей витаминной и антиоксидантной активностью характеризуется только альфа-токоферол, поэтому именно он нашел применение в медицине. Механизм его антиоксидантного действия заключается в переносе водорода фенильной группы на перекисный радикал при первичной встрече со свободным радикалом. Образующийся при этом радикал феноксил сам по себе достаточно стабилен и в продолжении цепи не участвует.

Синергичный эффект характерен для аскорбиновой кислоты (витамина С), восстанавливающей продукт окисления альфатокоферола альфа-токофероксид в альфа-токоферол. Суммарный антиоксидантный эффект альфа-токоферола не слишком выражен, поскольку в процессе нейтрализации свободных радикалов данным веществом образуются соединения с остаточной радикальной активностью. Другой недостаток альфа-токоферола заключается в его липофильности, что затрудняет создание лекарственных форм для парентерального введения, необходимых при оказании неотложной помощи. Однако у него есть и достоинства, главное из которых - крайне низкая токсичность как у эндогенного соединения $[66,68]$.

Витамин Е - один из наиболее изученных прямых антиоксидантов в целом и при мужском бесплодии в частности, что подтверждено рандомизированными клиническими исследованиями высокого уровня доказательности и метаанализами. Применяется он и в комплексном лечении ХП, но непосредственные результаты такой терапии пока неизвестны ввиду отсутствия рандомизированных клинических исследований соответствующего доказательного уровня [45].

\section{Миоинозитол}

Предшественник вторичных мессенджеров, миоинозитол вовлечен в различные сигнальные клеточные механизмы на уровне клеточных мембран, а также в процессы капаситации и активации акросомальной реакции сперматозоидов. Миоинозитол регулирует осмолярность спермоплазмы и ее объем, обеспечивает экспрессию генов белков для спермального хемотаксиса и подвижность сперматозоидов. В настоящее время нет научных данных о применении миоинозитола у пациентов с хроническими воспалительными заболеваниями придаточных половых желез, но при инкубации с миоинозитолом эякулята мужчин с нормозооспермией и патозооспермией отмечалось улучшение подвижности сперматозоидов. Рекомендуемая доза миоинозитола составляет 4 г/сут перорально плюс 400 мкг фолиевой кислоты в течение не менее двух месяцев [45].

\section{Фолиевая кислота (витамин B или витамин Вс, или фолиацин)}

Водорастворимый витамин, необходимый для роста и развития кровеносной и иммунной систем. Наряду с фолиевой кислотой к витаминам относятся и ее производные, в том числе ди-, три-, полиглутаматы и др. Их вместе с фолиевой кислотой объединяют под названием «фолаты». Фолиевая кислота биологически неактивна и только под воздействием фермента преобразуется в активную форму.

Коферментные функции дигидрофолиевой кислоты непосредственно связаны с переносом одноуглеродных групп, первичными источниками которых в организме являются производные хорошо известных аминокислот (серина, глицина, метионина, холина, триптофана, гистидина), а также формальдегид, муравьиная кислота и метанол. Производные дигидрофолиевой кислоты играют исключительно важную роль в биосинтезе белков и нуклеиновых кислот, поэтому неудивительно, что при недостаточности фолиевой кислоты нередко наблюдаются глубокие нарушения обмена. Фолиевая кислота обладает акцепторными свойствами по отношению к водороду, что определяет ее участие в окислительно-восстановительных процессах [66].

\section{Альфа-липоевая \\ (тиоктовая) кислота}

Один из самых мощных современных антиоксидантов. Альфалипоевая кислота была выделена в 1948 г. в клетках аэробов, а в 1951 г. получена из бычьей печени и исходно носила название «витамин N», что подчеркивало ее незаменимость для функции нервной ткани (витамины - незаменимые вещества, поступающие с пищей, N - «невро»). Однако витамином она не является по химической структуре, к тому же в небольшом количестве образуется в организме (показана способность Escherichia coli к синтезу этой кислоты), что не позволяет отнести ее к абсолютно незаменимым жирным кислотам [69]. В соответствии с современным уровнем знаний, альфа-липоевую кислоту классифицируют как витаминоид. Ее биосинтез может осуществляться не только в клетках бактерий и растений, но и в клетках высших организмов, в том числе в организме человека, где она находится в динамической системе с главным метаболитом - дигидролипоевой кислотой.

Альфа-липоевая кислота играет значимую роль в утилизации сахаров и нормальном энергетическом обмене. Через эпсилон- 
аминогруппу лизинового остатка она связывается с центральным компонентом ацилтрансферазы и действует как кофермент в ряде многоферментных комплексов митохондрий. Альфалипоевая кислота и особенно дигидролипоат (ее восстановленная форма) - важные антиоксиданты, работающие как в клетке (кофактор двух ферментов - дегидрогеназ цикла Кребса в митохондриях), так и вне ее (липофильность - гидрофильность) [70, 71].

Кроме того, альфа-липоевая кислота способна нейтрализовать гидроксильный радикал, синглетный кислород, пероксинитрит, гипохлорит и перекись водорода. Альфа-липоевая кислота также хелатирует металлы с переменной валентностью, участвует в восстановлении пула антиоксидантов (в частности, аскорбиновой кислоты и альфатокоферола), повышает внутриклеточный уровень глутатиона, модулирует активность некоторых транскрипционных факторов (например, фактора NF-кB). Дигидролипоевая кислота (но не альфа-липоевая кислота) дополнительно способна нейтрализовать супероксид-анион-радикал и пероксильный радикал.

Альфа-липоевая кислота - необходимый компонент в рецикле основных антиоксидантов, таких как витамин Е, глутатион, убихинон (коэнзим $\mathrm{Q}_{10}$ ) [72]. У нее также выявлена собственная антиоксидантная и липотропная активность, причем последняя заключается в ее способности активировать образование коэнзима А, облегчать перенос ацетата и жирных кислот из цитозоля в митохондриальный матрикс, ускорять окисление бета-жирных кислот и способствовать снижению липидов в плазме крови. Не так давно были опубликованы отечественные работы, демонстрирующие целесообразность и эффективность назначения альфа-липоевой кислоты в комплексной терапии различных категорий ХП [73, 74].

\section{Заключение}

Сегодня получены убедительные доказательства существенной негативной роли окислительного стресса в патогенезе практически всех современных заболеваний, а также установлены его многие молекулярно-клеточные механизмы. Окислительный стресс можно трактовать как каскадно протекающий и неконтролируемый процесс образования в клетках эндогенных свободных радикалов или избыточного поступления их извне (экзогенные свободные радикалы), приводящий к быстрому истощению и декомпенсации клеточных механизмов антиоксидантной системы защиты, что сопровождается патологическими клеточными реакциями. В самом общем виде они сводятся к резкому усилению процессов ПОЛ мембран всех клеток с накоплением в ней промежуточных и окончательных продуктов ПОЛ. Они сдвигают рН-баланс внутренней среды клетки в кислую сторону (метаболический ацидоз), вызывают дестабилизацию мембран клеток (мембранопатии), приводят к нарушению синтеза сигнальных клеточных белковых молекул и утрате контроля над процессами клеточной саморегуляции и аутофагии. В этой ситуации основной «свободнорадикальный удар» приходится на митохондрии клеток, которые в таких условиях не способны к полноценному и адекватному выполнению ключевых функций - синтезу энергии и обезвреживанию свободных радикалов (детоксикации), образование которых при окислительном стрессе носит цепной и неконтролируемый характер. В силу напряженности клеточных реакций антиоксидативной направленности и большого расхода запасов антиоксидантных субстанций в клетке быстро развивается дефицит эндогенных антиоксидантных и антигипоксантных субстанций, что в отсутствие соответствующей коррекции может закончиться апоптозом.
Несмотря на почти 200-летнюю историю изучения, ХП по-прежнему привлекает внимание клиницистов и исследователей, поскольку многие аспекты его патогенеза до сих пор не до конца понятны, а результаты лечения - зачастую неудовлетворительны с точки зрения как нормализации клинико-лабораторных параметров заболевания, так и улучшения качества жизни пациентов с ХП. И сегодня свободнорадикальная теория позволяет объяснить многие механизмы патогенеза воспалительных заболеваний предстательной железы.

Особенности окислительновосстановительного баланса при ХП продолжают активно изучаться в многочисленных клинико-экспериментальных исследованиях. Становится понятным, что независимо от природы этиологического фактора ХП (инфекционный или неинфекционный агент) важную роль на ранних стадиях заболевания играет окислительный стресс. Он негативно сказывается на метаболическом гомеостазе клеток предстательной железы, усиливая (часто уже без четкой связи с индуцировавшим хроническое воспаление агентом) анатомические потери и функциональные дефициты органа.

При лечении ХП урологи сталкиваются с целым рядом сложных клинических задач. В частности, с необходимостью обеспечить как можно более длительный период клиниколабораторной ремиссии, а еще лучше максимально восстановить все функции, утраченные в ходе длительного хронического воспалительного процесса независимо от его этиологии, то есть излечить больного, что в настоящее время пока представляется нереальным. Но это не означает, что от этой цели необходимо отказаться вовсе. Сегодня, когда доказана роль механизмов окислительного стресса при любой форме 
ХП, следует как активнее внедрять в рутинную клиническую практику методы оценки оксидативного статуса пациентов в целом и предстательной железы в частности, так и шире проводить антиоксидантное сопровождение фармакотерапии заболевания.

Для решения этой сложной клинической задачи на текущий момент, кажется, есть все условия. На рынке имеется большой класс препаратов с установленным антиоксидантным механизмом действия. При условии правильной предварительной оценки уровня и характера оксидативных нарушений в предстательной железе и применении фармакотерапевтических агентов с высоким уровнем доказательности в подавляющем большинстве случаев их прием позволяет защитить клетки предстательной железы от дополнительного свободнорадикального окисления (в том числе в связи с проводимой терапией, например, антибиотиками).

Однако нужно констатировать, что пока антиоксидантная терапия недостаточно широко используется при лечении боль- ных ХП. Кроме того, не так уж много антиоксидантов, которые эффективно проникают в предстательную железу в условиях ее воспаления. Но именно антиоксиданты, усиленные необходимыми микронутриентами (витаминами и микроэлементами), по нашему мнению, обеспечивают нормальный физиологический уровень протекания всех окислительно-восстановительных процессов в клетке, что позволяет эффективно управлять ключевыми звеньями негативного влияния окислительного стресса при ХП.

\section{Литература}

1. Урология. Национальное руководство / под ред. Н.А. Лопаткина. М.: ГЭОТАР-Медиа, 2009.

2. Простатит / под ред. П.А. Щеплева. М.: МЕДпресс-информ, 2007.

3. McNaughton Collins M., Barry M.J. Epidemiology of chronic prostatitis // Curr. Opin. Urol. 1998. Vol. 8. № 1. P. 33-37.

4. Wagenlehner F.M., Schneider H., Weidner W. Prostatitis syndrome // Urologe A. 2007. Vol. 46. № 2. P. 185-196.

5. Кульчавеня Е.В., Неймарк А.И. Простатит. Диагностика и лечение. М.: ГЭОТАР-Медиа, 2010.

6. Engeler D., Baranowski A.P., Borovicka J. et al. Guidelines on chronic pelvic pain. European Association of Urology, 2018.

7. Grabe M., Bartoletti R., Bjerklund Johansen T.E. et al. Guidelines on urological infections. European Association of Urology, 2018.

8. Mehik A., Hellström P., Lukkarinen O. et al. Epidemiology of prostatitis in Finnish men: a population-based crosssectional study // BJU Int. 2000. Vol. 86. № 4. P. 443-448.

9. Nickel J.C., Weidner W. Chronic prostatitis: current concepts and antimicrobial therapy // Infect. Urol. 2000. Vol. 13. № 5a. P. 22-28.

10. Белоусов И.И. Диагностика и лечение невоспалительной формы хронического абактериального простатита: автореф. дис. ... д-ра мед. наук. Ростов-на-Дону, 2014.

11. Тюзиков И.А., Иванов А.П. Абактериальный синдром хронической тазовой боли у мужчин как мультидисциплинарная проблема // Фундаментальные исследования. 2012. № 1. С. 121-124.

12. Тюзиков И.А. Взаимосвязь системных факторов в патогенезе синдрома хронической тазовой боли у мужчин // Урология. 2012. № 6. С. 48-51.

13. Roumeguère T., Sfeir J., El Rassy E. et al. Oxidative stress and prostatic diseases // Mol. Clin. Oncol. 2017. Vol. 7. № 5. P. 723-728.

14. Polackwich A.S., Shoskes D.A. Chronic prostatitis/chronic pelvic pain syndrome: a review of evaluation and therapy // Prostate Cancer Prostatic Dis. 2016. Vol. 19. № 2. P. 132-138.
15. Wang L.L., Huang Y.H., Yan C.Y. et al. N-acetylcysteine ameliorates prostatitis via miR-141 regulating Keap1/ Nrf2 signaling // Inflammation. 2016. Vol. 39. № 2. P. 938-947.

16. Pontari M.A., Ruggieri M.R. Mechanisms in prostatitis/ chronic pelvic pain syndrome // J. Urol. 2004. Vol. 172. № 3. P. 839-845.

17. Vaz C.V., Marques R., Maia C.J., Socorro S. Aging-associated changes in oxidative stress, cell proliferation, and apoptosis are prevented in the prostate of transgenic rats overexpressing regucalcin // Transl. Res. 2015. Vol. 166. № 6. P. 693-705.

18. Chen C.S., Chang P.J., Lin W.Y. et al. Evidences of the inflammasome pathway in chronic prostatitis and chronic pelvic pain syndrome in an animal model // Prostate. 2013. Vol. 73. № 4. P. 391-397.

19. Bostwick D.G., de la Roza G., Dundore P. et al. Intraepithelial and stromal lymphocytes in the normal human prostate // Prostate. 2003. Vol. 55. № 3. P. 187-193.

20. Motrich R.D., Maccioni M., Molina R. et al. Reduced semen quality in chronic prostatitis patients that have cellular autoimmune response to prostate antigens // Hum. Reprod. 2005. Vol. 20. № 9. P. 2567-2572.

21. Kullisaar T., Türk S., Punab M., Mändar R. Oxidative stress - cause or consequence of male genital tract disorders? // Prostate. 2012. Vol. 72. № 9. P. 977-983.

22. Кутлуев М.М. Состояние процессов свободнорадикального окисления в ткани предстательной железы при простатите (экспериментально-клиническое исследование): автореф. дис. ... канд. мед. наук. Нижний Новгород, 2011.

23. Plante M., de Lamirande E., Gagnon C. Reactive oxygen species released by activated neutrophils, but not by deficient spermatozoa, are sufficient to affect normal sperm motility // Fertil. Steril. 1994. Vol. 62. № 2. P. 387-393.

24. De Celis R., Pedron-Nuevo N., Feria-Velasco A. Toxicology of male reproduction in animals and humans // Arch. Androl. 1996. Vol. 37. № 3. P. 201-218.

25. Agarwal A., Sharma R.K., Desai N.R. et al. Role of oxidative stress in pathogenesis of varicocele and infertility // Urol. 2009. Vol. 73. № 3. P. 461-469. 
26. Tiseo B.C., Esteves S.C., Cocuzza M.S. Summary evidence on the effects of varicocele treatment to improve natural fertility in subfertile men // Asian J. Androl. 2016. Vol. 18. № 2. P. 239-245.

27. Божедомов В.А., Николаева М.А., Ушакова И.В. и др. Роль процессов свободно-радикального окисления в патогенезе мужского иммунного бесплодия // Андрология и генитальная хирургия. 2010. Т. 11. № 4. С. 62-66.

28. La Vignera S., Condorelli R.A., Vicari E. et al. Markers of semen inflammation: supplementary semen analysis? // J. Reprod. Immunol. 2013. Vol. 100. № 1. P. 2-10.

29. Кириленко Е.А., Онопко В.Ф. Окислительный стресс и мужская фертильность: современный взгляд на проблему // Бюллетень Восточно-Сибирского научного центра Сибирского отделения Российской академии медицинских наук. 2017. Т. 2. № 2. С. 102-108.

30. Кочмелев А.А., Хышиктуев Б.С., Терешков П.П. Некоторые параметры перекисного статуса спермоплазмы у мужчин с нарушением фертильности // Забайкальский медицинский вестник. 2012. № 1. С. 46-50.

31. Владимиров Ю.В., Проскурина Е.В. Свободные радикалы и клеточная хемилюминесценция // Успехи биологической химии. 2009. Т. 49. С. 341-349.

32. Мещанинов В.Н. Состояние перекисного окисления липидов системы крови в процессах возрастной инволюции организма и в условиях воздействия экстремальных факторов: дис. ... д-ра мед. наук. Екатеринбург, 1999.

33. Bartosz G. Total antioxidant capacity // Adv. Clin. Chem. 2003. Vol. 37. P. 219-292.

34. Леонтьев И.Г. Системная энзимотерапия при комплексной лазеромагнитоэлектростимуляции предстательной железы у больных с хроническим уретрогенным простатитом // Актуальные вопросы дерматовенерологии. Материалы ежегодной областной научно-практической конференции. Тюмень, 2003. С. 23-25.

35. Зарубина И.В., Мокренко Е.В., Шабанов П.Д. Метаболические и противовоспалительные эффекты иммуномодуляторов Трекрезана и Полиоксидония при экспериментальном простатите у крыс // Вестник Смоленской государственной медицинской академии. 2016. Т. 15. № 2. С. 15-21.

36. Голубчиков В.А., Ситников Н.В., Кочетов А.Г. и др. Оптимизация лечения доброкачественной гиперплазии предстательной железы с сопутствующим абактериальным хроническим простатитом (категория IIIa) // Урология. 2005. № 4. С. 9-12.

37. Новиков А.В. Использование фармакологических препаратов и методов антиоксидантной направленности у больных хроническим простатитом: дис. ... канд. мед. наук. М., 2005.

38. Orsilles M.A., Depiante-Depaoli M. Oxidative stress-related parameters in prostate of rats with experimental autoimmune prostatitis // Prostate. 1998. Vol. 34. № 4. P. 270-274.

39. Луичкий Д.Л., Махмудов Р.М., Луизкая А.М. Исследование эякулята и его компонентов в диагностике воспалительных заболеваний мужской репродуктивной системы: ферменты, простатосомы // Проблемы репродукции. 2011. Т. 17. № 3. С. 82-84.

40. Potts J.M., Pasqualotto F.F. Seminal oxidative stress in patients with chronic prostatitis // Andrologia. 2003. Vol. 35 № 5. P. 304-308.
41. Condorelli R.A., Russo G.I., Calogero A.E. et al. Chronic prostatitis and its detrimental impact on sperm parameters: a systematic review and meta-analysis // J. Endocrinol. Invest. 2017. Vol. 40. № 11. P. 1209-1218.

42. Zhou J.F., Xiao W.Q., Zheng Y.C. et al. Increased oxidative stress and oxidative damage associated with chronic bacterial prostatitis // Asian J. Androl. 2006. Vol. 8. № 3. P. 317-323.

43. Dai C.F., Zhang Z.Z., Qi X.L. et al. Clinical and experimental study of treatment of nanmiqing capsule for chronic prostatitis // Zhonghua Nan Ke Xue. 2002. Vol. 8. № 5. P. 379-382.

44. Xu S.B., Li S.W., Zheng X.M., Hu L.Q. Treatment of experimental chronic bacterial prostatitis with free-radical scavenger in rats // Zhonghua Nan Ke Xue. 2005. Vol. 11. № 1. P. 47-49.

45. Antioxidants in andrology (trends in andrology and sexual medicine) / ed. by G. Balercia, L. Gandini, A. Lenzi, F. Lombardo. Switzerland: Springer, 2017.

46. Толпыгина O.A. Роль глутатиона в системе антиоксидантной защиты (обзор) // Бюллетень ВосточноСибирского научного центра Сибирского отделения Российской академии медицинских наук. 2012. № 2-2. C. $178-180$.

47. Irvine D.S. Glutathione as a treatment for male infertility // Rev. Reprod. 1996. Vol. 1. № 1. P. 6-12.

48. Bornman M.S., du Toit D., Otto B. et al. Seminal carnitine, epididymal function and spermatozoal motility // S. Afr. Med. J. 1989. Vol. 75. № 1. P. 20-21.

49. Vicari E., La Vignera S., Calogero A.E. Antioxidant treatment with carnitines is effective in infertile patients with prostato-vesciculo-epididymitis and elevated seminal leukocyte concentration after treatment with non-steroidal anti-inflammatory compounds // Fertil. Steril. 2002. Vol. 78. № 6. P. 1203-1208.

50. Ciftci H., Verit A., Savas M. et al. Effects of N-acetylcysteine on semen parameters and oxidative/antioxidant status // Urology. 2009. Vol. 74. № 1. Р. 73-76.

51. Аронов Д.М. Что важно знать практическому врачу об убихиноне (коэнзиме Q10) // РМЖ. 2006. Т. 14. № 4. C. 223-230.

52. Медведев О.С., Каленикова Е.И., Городеикая Е.А., Шашурин Д.А. Коэнзим Q10 в кардиологической практике: теоретические основы и результаты клинических исследований // РМЖ. 2009. Т. 17. № 18. С. 1177-1181.

53. Болдырев А.А. Карнозин. Биологическое значение и возможности применения в медицине. М.: МГУ, 1998.

54. Саяпина И.Ю., Целуйко С.С., Чередниченко О.А. Биологическая роль цинка в предстательной железе (молекулярные аспекты) // Дальневосточный медицинский журнал. 2015. № 2. С. 137-143.

55. Агаджанян Н.А., Скальный А.В. Химические элементы в среде обитания и экологический портрет человека. М.: Изд-во КМК, 2000.

56. Циммерманн М. Микроэлементы в медицине (по Бургерштайну). М.: Арнебия, 2006.

57. Скальныц А.В. Химические элементы в физиологии и экологии человека. М.: ОНИКС 21 век, 2004.

58. Tato Rocha R.E., Cárdenas Viedma E., Herrero Huerta E. Selenium: the physiopathological and clinical implications // An. Med. Interna. 1994. Vol. 11. № 9. P. 457-463. 
59. Степанов Ю.М., Кононов И.Н., Журбина А.И., Филиппова А.Ю. Аргинин в медицинской практике // Журнал АМН України. 2004. Т. 10. № 1. С. 340-352.

60. Бабушкина A.B. L-аргинин с точки зрения доказательной медицины // Украинский медицинский журнал. 2009. № 6. C. 56-62.

61. Алмакаева Л.Г., Литвинова Е.В. Аргинин и его применение в медицине и фармации // Лики Украины. 2001. № 1. C. $23-26$

62. Pyo K.H., Lee Y.W., Lee S.H. et al. Preventive effects of resveratrol-enriched extract of peanut sprout on bacteria- and estradiol-induced prostatitis in mice // Nat. Prod. Commun. 2017. Vol. 12. № 1. P. 73-78.

63. He Y., Zeng H., Yu Y. et al. Resveratrol improved the progression of chronic prostatitis via the downregulation of c-kit/SCF by activating Sirt1 // J. Agric. Food Chem. 2017. Vol. 65. № 28. P. 5668-5573.

64. He Y., Zeng H.Z., Yu Y. et al. Resveratrol improves prostate fibrosis during progression of urinary dysfunction in chronic prostatitis // Environ. Toxicol. Pharmacol. 2017. Vol. 54. P. 120-124.

65. Yu Y., Jiang J., He Y. et al. Resveratrol improves urinary dysfunction in rats with chronic prostatitis and suppresses the activity of the stem cell factor/c-Kit signaling pathway // Mol. Med. Rep. 2017. Vol. 16. № 2. P. $1395-1400$.

66. Ших Е.В., Махова А.А. Витамины в клинической практике. М.: Практическая медицина, 2014.

67. Livera G., Rouiller-Fabre V., Durand P., Habert R. Multiple effects of retinoids on the development of Sertoli, germ, and
Leydig cells of fetal and neonatal rat testis in culture // Biol. Reprod. 2000. Vol. 62. № 5. P. 1303-1314.

68. Duncan K.R., Suzuki Y.J. Vitamin E nicotinate // Antioxidants (Basel). 2017. Vol. 6. № 1. P. 20-28.

69. Reed L.J., Debusk B.G. A conjugate of alpha-lipoic acid required for oxidation of pyruvate and alpha-ketoglutarate by an Escherichia coli mutant // J. Biol. Chem. 1952. Vol. 199. № 2. P. 873-880.

70. Moura F.A., de Andrade K.Q., dos Santos J.C., Goulart M.O. Lipoic acid: its antioxidant and anti-inflammatory role and clinical applications // Curr. Top. Med. Chem. 2015. Vol. 15. № 5. P. 458-483.

71. Park S., Karunakaran U., Jeoung N.H. et al. Physiological effect and therapeutic application of alpha lipoic acid // Curr. Med. Chem. 2014. Vol. 21. № 32. P. 3636-3645.

72. Барабой В.А. «Альфа-липоевая - дигидролипоевая кислоты» - активная биоантиоксидантная и биорегуляторная система // Укр. біохім. журн. 2005. Т. 77. № 3. С. 20-26.

73. Тюзиков И.А., Калинченко С.Ю., Ворслов Л.О., Тишова Ю.А. Роль окислительного стресса в патогенезе андрологических заболеваний. Тиоктовая (альфа-липоевая) кислота - новые грани фармакотерапевтических опций в современной андрологической практике // Эффективная фармакотерапия. 2018. № 9. С. 20-37.

74. Можаев И.И., Тюзиков И.А., Шорманов И.С. Роль невропатического компонента и современные возможности его патогенетической фармакологической коррекции при синдроме хронической тазовой боли (СХТБ) IIIB категории у мужчин // Эффективная фармакотерапия. 2017. № 34. C. 14-21.

\title{
Antioxidant Maintenance for Pharmacotherapy of Chronic Prostatitis:
} Pathogenetic Feasibility and Effectiveness

\author{
O.I. Bratchikov, MD, PhD, Prof. ${ }^{1}$, I.A. Tyuzikov, $\mathrm{PhD}^{2}$, P.A. Dubonos ${ }^{1}$ \\ ${ }^{1}$ Kursk State Medical University \\ ${ }^{2}$ Medical Center 'Tandem-Plus', Yaroslavl
}

Contact person: Igor A. Tyuzikov, phoenix-67@list.ru

Currently, one of the most popular and evidence-based theories of aging and the pathogenesis of human diseases is the free-radical theory (the theory of oxidative stress), in which oxidative stress is considered as one of the key universal mechanisms of aging and pathogenesis of the vast majority of modern human diseases. Based on modern clinical and experimental studies, the review article addresses the general issues of the pathophysiology of oxidative stress and its role in the pathogenesis of chronic prostatitis. The pharmacological embodiment of the theory of oxidative stress has been the synthesis and introduction into clinical medical practice of an extensive group of antioxidant drugs, the list of which is currently constantly expanding. This is due to the fact that different antioxidants differ significantly from each other both in chemical structure and in functional load and the point of application of effects. In this regard, in various fields of medicine, a specific arsenal of the most studied and effective antioxidants from the point of view of evidence-based medicine and pharmacology have formed to date. In urology, its own pharmacological base of antioxidants is also formed taking into account the specific pathogenesis of urological diseases, including chronic prostatitis. In this regard, the article provides a more detailed overview of modern antioxidants, promising from the point of view of the use of chronic prostatitis in complex pharmacotherapy, as well as an analysis of the available evidence on their effectiveness. Based on an analysis of the available literature that reflects the essential role of oxidative stress in the pathogenesis of chronic prostatitis, it is concluded that the additional use of antioxidant therapy for chronic prostatitis is advisable and effective in order to increase the effectiveness of existing pharmacotherapy methods for this disease.

Key words: chronic prostatitis, oxidative stress, reactive oxygen species, lipid peroxidation, antioxidant defense system, antioxidants 